\title{
LAW AND GLOBALIZATION: A CRITIQUE OF A DIALECTIC RELATION
}

\section{DIREITO E GLOBALIZAÇÃO: CRÍTICA DE UMA RELAÇÃO DIALÉTICA}

\author{
Salem Hikmat Nasser \\ JOSÉ GARCEZ GHIRARDI**
}

\begin{abstract}
The connections between Law or, more broadly, normativity, and globalization have been the object of intense scholarly scrutiny for the past three decades. This debate has produced expressions such as "Global Law", re-signified "Transnational Law" and explored notions such as "Internationalization of Law". Such literature has not translated, however, into conceptual consensus, nor has it been able to fully explore the complex interplay between two of the central concepts in the field, namely, "Law of globalization" and "Law in globalization". This paper discusses and problematizes the connections between these two concepts. It aims at highlighting the complexities involving the debate on normativity and globalization, and at pointing out to risks that some of the dynamics involved in these dimensions pose to the rule of Law. The argument starts with a critical review of the literature on the field, and then presents the descriptive-analytical perspective it adopts to examine this phenomenon; its final section discusses some problematical implications of the relation between Law of globalization and Law in globalization.
\end{abstract}

KEYWORDS: Globalization. Global Law. Transnational Law. Law in Global Context. Law of Globalization.

\section{RESUMO}

A interconexão entre Direito, ou normas de modo geral, e globalização tem sido apontada por extensa literatura, que cobre ao menos três décadas. Ela produziu expressões como "Direito Global", deu novos sentidos a "Direito Transnacional" e explorou noções como "Internacionalização do Direito". Essa literatura não resultou, no entanto, em consensos conceituais, nem se esgotou a exploração do complexo universo de modos em que a interação se dá. Este artigo propõe uma organização da reflexão em torno de duas noções centrais para esse campo, a saber, a de "Direito da globalização" e a de "Direito na globalização". Esse artigo discute uma visão própria e problematizada das relações entre esses termos. O texto tem por objetivo apontar caminhos para a compreensão da complexidade das interações entre normatividade e globalização e alertar para os riscos de algumas dessas interações complexidade para o estado de direito. O argumento inicia com a apreciação crítica de uma vasta literatura, apresentando depois a chave descritiva e analítica a ser aplicada ao tema e problematiza e às implicações das interações que tem por objeto.

PALAVRAS-CHAVE: Globalização. Direito Global. Direito Transnacional. Direito em contexto Global. Direito da Globalização.

* Professor na Fundação Getúlio Vargas Escola de Direito de São Paulo. Doutor pela Universidade de São Paulo. E-mail: Salem.Nasser@fgv.br.

* Professor na Fundação Getúlio Vargas Escola de Direito de São Paulo. Doutor pela Universidade de São Paulo. E-mail: jose.ghirardi@fgv.br. 


\section{INTRODUCTION}

Law and globalization are inextricably linked. The new modes of international transactions in the economic, political and social arenas which characterize the global age have been shaped by and translated in legal normativity. ${ }^{1}$ A key feature of globalization is, indeed, the rise of supra- or extraState normativities, ${ }^{2}$ and the corresponding push to move, as de Kerchove and Ost suggest, from government to governance, from pyramid to network, from national government to global governance. ${ }^{3}$

Debates centering on the purported waning of the State have at their core the perceived loss of capacity by individual national States to effectively regulate phenomena which are intrinsically global in nature, such as climate change, immigration, human rights, food and health security. In this arena, coordination among nations and other agents is deemed unavoidable. Municipal law is severely limited in this context.

Limited, one must concede, but not irrelevant. On the contrary. Globalization may have created a new horizon for municipal law, but its success remains crucially dependent on it. In Law, as in other dimensions, globalization is characterized by the specific kind of tension it establishes between local and global, between domestic and foreign, between culturally determined and (supposedly) universal practices.

This paper suggests that this dialectics of global/local put in movement by globalization has, for the last thirty years or so invited legal scholars to focus on the corresponding dialectics this movement generates in Law. During this period numerous works in legal literature have dealt with the theme of the interaction between law and globalization. ${ }^{4}$ Expressions such as "transnational law", "global law", and notions such as "internationalization of law" or "t globalization of law" have become common and current. However, this rich literature has nor translated into a consensual definition of transnational law or of global law. Sometimes, what is meant by these concepts is a type of legal system, unitary and coherent, which is imagined as being truly global in the sense that it encompasses the whole world. Some other times the expression

\footnotetext{
1 GROSS CUNHA, 2018, p.2.

2 CHEVALLIER, 2017.

3 OST and KERCHOVE, 2002.

4 A few notable examples are Mirelle DELMAS-MARTY, 1998; Peter ZUMBANSEN, 2012; Paul KJAER, 2013, 2019; Pierrick LE GOLF, 2007; Paul SCHIFF BERMAN, 2014; Gianluigi PALOMBELLA, 2019; William TWINING, 2010; Hans LINDAHL, 2014; Richard COLLINS, 2017; Neil WALKER, 2014; Martin SHAPIRO, 1993; Martin LOUGHLIN, 2017 and, within the Brazilian legal landscape, we can mention at least José Eduardo FARIA, 1996 and Salem NASSER, 2015.

5 This expression is itself much older than the debate on globalization and law, as it has been coined by Jessup in 1956.
} 
is used to convey some set of ideas related to legal pluralism. Very often, the notions are associated with a specific theme or legal regime that is thought to be transnational in nature.

Our aim is not to cover and scrutinize this abundant body of writings. The absence of consensus on definitions and on the thematic scope seems to bespeak the fact that globalization is an ongoing, continuous and multifarious process. The work of understanding is interaction with law and other kinds of normativity, and of understanding its fast-changing dynamics is, therefore, a continual endeavor.,. This authorizes us to add our brick to the impressive wall of established scholarship in the matter.

This paper argues that in order to a key element to understand the connections between Law and globalization is the distinction between what we can call the law of globalization and what happens to law in a context of globalization. The ever-expanding universe of norms, many belonging to legal systems and many other which are not properly speaking legal - and, therefore, are not part of any legal order -, makes this distinction elemental to offer a nuanced reading of the interplay between normative systems and that of globalization.

The former, as it is posited here, refers to norms and rules, of different kinds, which have as their purported normative reach global transactions. Their goal is to create the normative infrastructure necessary to allow for the free flow of goods, investments and people which makes for globalization.

The latter notion, law in globalization, refers to the multiplicity of norms and rules, belonging to different legal systems and to other normative ensembles, as they come into various types of interaction in order to deal with the growing universe of relations and exchanges that transcend the national borders but affect national States individually and their nationals as well. Their goal is, in part, to create the normative infrastructure necessary for the social and economic advance of national societies in the context of globalization. Within national legal systems, the impact of globalization on norms will be arguably different - it is likely to suppose that contract law will be much more directly affected than family law, for example. These differences notwithstanding, it is possible to hold that even those areas less evidently touched by the new global scenario embody the broader set of concerns generated by it.

This paper holds that these two dimensions bear a dialectic relationship in the sense that neither can ignore the other, nor function without the other, at the same time that they are irreducible to each other. Their logic of construction is markedly different while the normative language they deploy presents important similarities. Law of globalization and law in globalization may be seen as the manifestation, in the legal arena, of the contradictory forces shaping 
globalization. ${ }^{6}$ The analysis of the relationship between the two is the object of this text.

This paper is divided in four sections. The first discusses different concepts of globalization and their implication; and it presents the concept of globalization adopted for this argument. The second section discusses global law as the law of globalization and describes its main features. The third analyses law in globalization, dealing with the main features of what constitutes a whole, understudied, field of concern, namely, the whole complex of normative and institutional interactions that take place under the influence of globalization. The fourth concludes by summarizing the argument and pointing out to the methodological implications springing from the conceptual distinction argued here.

\section{GLOBALIZATION}

It is a cornerstone of Modern discourse and imagination that all human interaction happens in a world shaped in the form of a globe. It would be hard to overstate the impact that this geographical discovery has had as it shattered century-old beliefs, metaphors and legitimation discourses. Modern concepts of diversity of culture and forms of polity break away from medieval thought to a large extent by incorporating to its ideological framework the notion that we live in a round world, with no determined top or down, and where spatial location shapes perception of right and wrong, lawful and unlawful. The shrewd observations of Gulliver as he travels around the world could emerge only in a society for which the diversity of the globe was taken as a given.

This indisputable fact may serve as the first step towards an understanding of what exactly may be meant by the word "Globalization", so intensively used during the past 30 years. The successive rendering of this now everyday concept may serve as the starting point towards understanding something about the state and the transformations of human interaction, in general, and of law, in particular, since the last decades of the 20th century.

The French preference for the alternative expression "Mondialisation" conveys in an even more straightforward manner the same basic question and its potential contradictory answers: what does it mean to say that social processes become "worldly"? Though there are many different renderings of the distinction between mondialisation and globalization within the French academy, the distinction offered by Henry Bartoli seems to encapsulate the key issues at stake:

What becomes "global" tends to become a whole governed by rules in such a manner that the whole thus organized constitutes a "system". Conversely,

6 SANTOS, 2002. 
what becomes "mondial [from monde, world]" creates multiple links and interconnections between the nation-states, the corporations, the societies in such a manner that the events, the decision taking place in one part of the planet affect more or less directly individuals and groups living elsewhere.

This conceptual cleavage between a rule-governed-system and a network of interconnected individuals is a testimony to the dual nature of globalization, to its being necessarily a phenomenon which re-signifies, but does not do away with, the local.

It is arguable that much of the controversy around the meaning of globalization is rooted in the different manners authors conceptualize and assess its dialectic nature. As any discursive topos, it must revolve around some central, shared idea. Its specific meaning, nevertheless, will vary according to the diversity of communities and discourses. As Hayden White has observed in his seminal Metahistory:

"[...] there are no apodictically certain theoretical grounds on which one can legitimately claim an authority for any one of the modes [of narrating history] over the others as being more "realistic" [...] as a consequence of this, we are indentured to a choice among contending interpretive strategies in any effort to reflect on history in general". ${ }^{8}$

This is why every time one encounters the word globalization, the first, necessary, interpretive task is to establish what exactly is meant by its use, what aspects of the transformations in societal relations are highlighted, what types of exchanges are encompassed, what is the reach of the phenomena etc. To use White's concept, the first task is to decide on the narrative mode one will choose to posit a certain causality between events. The ongoing struggle around the political and social implications of globalization is, at its root, both a clash between narratives and an opposition between addressers and adressees, who often question dominant renderings of the phenomenon.

It is not our aim to establish a comprehensive map of all possible conceptions of globalization. It is not clear that such a task of tracking all existing uses of the word is even feasible. They will tend, however, to either focus on some aspect, on some area of life, speaking of economic, cultural, social, political globalization, or try a more encompassing perspective.

In this paper, we will stress one dimension which must perforce be present in every conception of the word, namely, that of a progressive densification of

7 «Ce qui se «globalise», rappelle-t-il, tend à devenir un ensemble régi par des règles telles que le tout organisé constitue un «système». » A l'inverse, « ce qui se «mondialise» tisse de multiples liens et interconnexions entre les Etats-nations, les entreprises, les sociétés de telle sorte que les événements, les décisions survenant en un lieu de la planète retentissent plus ou moins intensément sur les individus et les collectivités vivant en d'autres lieux » Our translation. https://www.scienceshumaines.com/globalisation-versus-mondialisation_fr_1044.html BARTOLI, 2000 ; DUMEZ and JEUNEMAITRE, 2000. WHITE, 1973. 
a net of human exchanges and social processes and interactions, in a context in which this net encompasses the whole globe, the whole world. As Anthony Giddens puts it: "Globalization can thus be defined as the intensification of worldwide social relations which link distant localities in such a way that local happenings are shaped by events occurring many miles away and vice versa."

This all-encompassing net of relations and exchanges has arguably been under construction - or undergoing a spontaneous process of formation since the dawn of human societies, since the first hypothetical time in which members of two distinct groups of people met and related to each other. We may, understandably, not have thought of calling this very long historic process globalization until the day we somehow realized that the net had already succeeded in covering the whole world and was, with increasing velocity, becoming more and more dense. The fact remains, nevertheless, that globalization is the result of this accumulated human experience.

Whatever interaction we may choose to call local is not excluded from the net of Globalization in this fundamental and more general sense we are discussing here. On the contrary, the very notion of local, as currently used, cannot be fully grasped if not referred to its counterpart global. The dialectics of global-local, and the attempts of synthesis such as the one represented by glocal bespeak a new scenario, in which the traditional distinction national/ international loses prestige due to, to a large extent, to the reconfiguration of the role of national States as meaningful players in the transnational arena.

In the present scenario, local interactions cannot but participate in the process of making denser the net of human relations and exchanges. This implies that, the local is necessarily transformed by the significant contacts it establishes with the national, the regional, the international, the transnational, the supranational and with the properly global. The same is true for each of the levels in this chain of locals in relation to the sequence of more encompassing concentric circles:

Globalization can be on a continuum with the local, national and regional. At one end of the continumm lie social and economic relations and networks which are organized on a local and/or national basis; at the other end lie social and economic relations and networks which crystallize on the wider scale of regional and global interactions. Globalization can refer to those spatial-temporal processes of change which underpin a transformation in the organization of human affairs by linking together and expanding human activity across regions and continents. Without reference to such expansive spatial connections, there can be no clear or coherent formulation of this term. ... A satisfactory definition of globalization must capture each of these elements: extensity (stretching), intensity, velocity and impact. ${ }^{10}$

9 GIDDENS, 1990.

10 HELD, 1999. 
Of course, an observer may, in accordance with the elements that command his point of view, his perspective, see, or regard as significant, only a bundle or a bunch of lines and knots of the totality of the net, in order to call this ensemble globalization. As pointed out by White, the selective is the result of an inevitable choice.

Among the criteria for the delimitation of what specifically is globalization are: i) the geographical reach, that is to say, a key component of the phenomenon would be the fact that is properly speaking global in reach, covering countries in all corners of the world; ii) the thematic import, that is to say, the type of activity is singled out as the most relevant to identify a global interaction - as, for instance, economic relations.

As we do not intend to map all possible conceptions of globalizations, we will not, either, choose one of the conceptions as being ours, neither one of the criteria as being more relevant. We will deploy our central notion of the densification of a net of exchanges, fluxes and relations, to suggest that, regardless of the definition chosen, the idea of globalization produces, inevitably, a type of summa divisio.

We propose, as an intellectual exercise, to distinguish between globalization as a spontaneous process, i.e., as a natural tendency of the human being and of human societies to make use of whatever roads are opened by technological advances to advance further and go towards others, and globalization as a project, i.e., as a human construct of intentional integration.

We are aware of how artificial it is to conceive of a perfect differentiation between project and spontaneity of the social processes we are talking about. A look at the technological advances that are at work in the social network revolution should suffice as evidence of the difficulty to establish the borders separating one from the other. Just as we see how naturally people occupy the new spaces opened to interaction with others, we observe also how clear it is that such spaces were created by purposeful agents.

Spontaneity and project are in constant interplay, involving different agents at different times. There is no reason to believe, thus, that there are "pure forms" of each of these drives, nor that there are no projects at work underneath the apparently spontaneous actions of individuals since the intentladden creation and realization of the structures within which such actions take place determine, to a large extent, the horizon of their potential uses.

The usefulness of our proposed distinction is that it helps our effort to distinguish and clarify two types of phenomena occurring simultaneously in the legal arena. Distinguishing between globalization as a spontaneous process and globalization as a project is instrumental to establishing the distinction between the place of law in the construction of globalization, on one hand, and, on the other hand, the effects of globalization on law. If there is no doubt that 
globalization and law entertain intimate relation - some going as far as to claim that globalization is, at its core, a legal phenomenon -, there is less certainty about the nature of these relations. What are the traits of the interaction between law and globalization?

It seems clear that, in as much as globalization is a creation, it is the product of an intent. globalization does not just happen, as a natural phenomenon, it is the result of the deliberate enacting of rules and norms, of the designing, implementation and funding of institutions. Rules, norms and institutions are, of course, the product and the object of law. This dimension is what we choose to call the law of globalization.

As suggested above, however, globalization is not only, nor even primarily, the result of the straightforward intent of actors as translated in rules, norms and institutions. It is also the response that different societies, groups and communities give to the new realities which spring from a changed institutionalnormative framework. Law responds to as much as enables the integration which is constitutive of globalization. The other dimension of law is also made up by norms and institutions, but, in this sphere, they apply and create them specifically - as much as possible - to respond to globalized interactions. Both will be dealt with in the following section.

For the moment it is enough to point out that it is also certain that most of law does not participate in the construction of the structures that aim primarily at setting in motion the Globalization process and does not have as its focal point globalized relations. Most of law suffers the impacts of the globalization processes.

It follows from the above that no encompassing analysis of the relations between law and globalization will be possible if both these dimensions, as well as the complex interactions between them, are not taken into account. The discussion of what happens to law in general in these conditions is what we call the Globalization of Law. This will be the object of section III.

Before we go further, it is important to clarify that for the purposes of this paper we are accepting an expanded conception of law, one that is basically referring to a large array of normativity. This expanded view is important specially to take into account the norms that organize the process of Globalization, as they are not always the product of the legislative operations of states or of interstate processes.

The expansion does not mean, however, undifferentiation, since the consequences of the interaction of norms, brought by Globalization, vary according to the origin and nature of the norms involved. 


\section{GLOBAL LAW AS THE LAW OF GLOBALIZATION}

As it has been said, there is abundant literature on the interplay between law and globalization. Within this production the expression Global Law has emerged as an attractive topos for many.

The meaning and reach of the expression are not the same for all of its users, however. Paul Kjaert, who has written extensively on the subject, has recently articulated some critical remarks towards the literature on Global Law, ${ }^{11}$ which included the denunciation of a conceptual flaw intrinsic to some arguments on the field. Such flaw consisted in either considering that Global Law was a "a unitary law producing singular legal norms with a planetary reach" or considering that a "radical pluralist perspective is [to be] adopted dismissing the existence of singular global norms." 12

Kjaert himself offers us a third, alternative view of Global Law as he invites us to understand "global law and its related legal norms as a de-centred kind of inter-contextual law characterized by inter-legality." This means, that all other types of law, national, international, transnational, living, may function as sources for Global Law but are not to be confused with it, since main function of the latter is to provide for inter-legal connectivity, and this is reflected in its structural features:

Reflecting its inter-legal structure, the substantial normative content of global law is furthermore characterized by a relative structural predominance of connectivity norms. Connectivity norms are oriented towards the facilitation of transplantations, i.e., the extraction, transmission and incorporation of components of meaning, from one legally structured context to another as, for example, is the case within international trade and investment law, internal market law or legally sanctioned missionary activities within religious law. ${ }^{13}$

We are therefore presented with three general possibilities for the discursive use of the expression Global Law: i) a unitary body of rules, whether we want to see it as an all-encompassing single ensemble applying to all of humanity, or as a much more limited set of norms applying to interactions that are properly speaking global in themselves; ii) an approach that looks at the multiplicity of legal systems and normative bodies and their interaction; iii) and the perspective that sees essentially the connectivity norms as being global.

The third perspective, though a very sophisticated one, fails to offer us a glimpse of what norms should be included there. In a sense, it does not refuse the possible existence of norms that deal specifically with global themes and matters, and it certainly does not deny the multiplicity of legal systems which

\footnotetext{
11 KJAERT, 2019.

12 Idem.

13 Idem.
} 
are called to interact, by globalization. It proposes, in fact, that the specific role for Global law would be that of providing the connections for the interaction.

In this first approach to the law of globalization, we mean to deal with law that, whatever its provenance, may be looked at as specifically global due to its function or goal of constructing a global framework and creating means for its enforcement within national States.

In the following section, our approach will be more oriented towards the pluralist perspective. Before that, however, we will discuss Global Law as the law by which globalization is built and as the law that applies specifically to global processes.

As mentioned, one of the most referred facets of Globalization is the densification of economic relations. For many, globalization means indeed economic globalization. This is hardly surprising. Economic aspects of globalization happen to offer us one of the clearest examples of what we call here the law that constructs and implements globalization.

Joseph Stiglitz, an author who offers a sharp criticism of the globalization process ${ }^{14}$ focuses on the international structure of the world economy, a structure of which he has been a long-time participant. This institutional framework has been put in place by agreements between states, agreements arrived at much before the discourses on globalization became commonplace. The mainstays of such structure are the World Bank, the International Monetary Fund (IMF) and the international trade system, which began as the General Agreement on Trade and Tariffs (GATT) and developed into the World Trade Organization (WTO).

As we know, this three-faceted system of the world economy was conceived after World War II and was meant to be global. ${ }^{15}$ The agreements and the institutions put in place to open the roads for the economic interactions between all the of the States, were dominated by an ethos and by a specific economic perspective, one that saw the freedom of interaction as a good to be fostered by all. The postwar world was eager to reinstate the faith in Montesquieu's "doux commerce" and in its supposed civilizing virtues.

This liberal view on global integration, which was embodied by the above-mentioned triptych and its functioning, has been deepened as the system developed and became more complex, and more ambitious, over the years. It was its combination with the so-called Washington Consensus, ${ }^{16}$ in the 1990 's, that triggered the identification of the globalization process as a primarily economic enterprise. Harsh criticism of this synecdochal reading of process and of its practical outcomes was immediately heard.

14 STIGLITZ, 2002.

15 Agreements of the 1944 Breton Woods Conference.

16 SANTOS, 2002, p. 75. 
One of the phenomena made possible by the architecture of multilateral trade, combined with the law of international investments is that of the global value-chains, which are constructed by contractual nets that organize the action of multinational enterprises. ${ }^{17}$

Also, a creation of private actors is the whole architecture of the Internet, which is today the most travelled road of the globalization process.

The notion of norms that apply to actions and facts that transcend national borders is not new. In 1956, Philip Jessup chose to call the totality of these legal norms Transnational Law. ${ }^{18}$ The choice of the name was indeed clever and had, as it continues to have, several important implications.

It clearly differentiates this normative ensemble from national law exclusively domestic and created by the State - and from international law - the law that rules over interstate relations and is also created by the states. This differentiation does not entail the hermetic closing of one ensemble in relation to the others. It has, additionally, the advantage of focusing on the relations that "transcend" national borders, relations that can be seen as piercing these frontiers, of ignoring them, of floating over them, relations that are not to be seen as simply "inter-national".

It was also a clever choice in that it differentiated between this loosely considered ensemble of norms (transnational law) and other sets of norms which also deal with cross border interactions, but that are more specific in scope or meaning. One such law is the private international law (or conflict or laws in the American tradition) that is a part of national law regulating competence, applicable - national - law and recognition of foreign decisions in cases that are private and connected to more than one domestic legal system. Another such set is supranational law, a law that, by States acceptance, is produced at an exterior instance and applies to States behavior (the virtually sole example of this is European Community Law).

Transnational law remains loosely defined, however, and it may very well include many norms that are part of national systems or of international law, since there is no doubt that domestic and international law both deal with situations that "transcend national borders" and that are not specifically international (meaning here inter-state).

One evidence of the fact that both municipal and interstate law deal with what transcends national borders is provided by a development in the use of the expression transnational law, which, for many, was thought to designate specifically the norms applying to international investment relations, and more

17 BACKER, 2007.

18 JESSUP, Phillip. Transnational Law, New Haven, Yale University Press, 1956, apud SALMON 2001, pg. 394 : "tout le droit qui réglemente les actions ou les événements qui transcendent les frontières nationales". 
particularly to the interactions between States and foreign investors. ${ }^{19}$ It is clear that these interactions are governed both by national and international law, even if they may know also norms produced elsewhere.

But can we say that all law that applies to acts and situations that transcend national borders is Global Law in the sense we have suggested here, as the law that applies to fluxes and exchanges that constitute globalization?

Of course, if we have accepted each interaction, however local, as one more line to participate in the thickening of the global net, then it would be fitting to consider this broadly considered transnational law to be, at least partly, global. Some of the situations that transcend national borders do in fact go as far as covering the whole globe, and they are covered by norms that proceed from various sources.

Interestingly enough, one of the phenomena that are clearly global in reach is one regulated by a law that is older than international law itself. Indeed, the commercial exchanges between traders in every corner of the world are essentially governed by their own practices and customs, known as lex mercatoria, of which the roots extend centuries back. Lex mercatoria is today closely linked to another set of norms, viewed as global or at least as transnational, that corresponds to what we are calling law of globalization, and that is the field of international commercial arbitration. ${ }^{20}$

Of course, for the more recent phenomena that we associate more properly with the globalization that has taken place in the last decades - or that part of globalization, or its acceleration that has taken place in this period - notably the distribution throughout the globe of economic, financial and technological interactions, the same norms that have brought this globalization into existence are at the same time norms that govern it in the specific fields.

These norms are joined however by others, produced in other loci, national or international, and by other actors, states or private, that will try to govern the same global phenomena or exchanges. ${ }^{21}$

Another sense in which law may be deemed global, meaning that it governs specifically global phenomena, is the response that law tries to offer to concerns that are relevant for the whole of the earth, for the continuity of the ecological equilibrium and for the possibility of human life in the planet. Indeed, the law dealing with climate change, with biodiversity and other such themes can only be global in the sense that it either deals with the whole globe or it makes no sense.

Finally, one can conceive of law that is specifically global in the sense that it deals with values that can be said to be those of Humanity as a whole. In

19 SALMON, idem.

20 FOZ MANGE, 2016.

21 This idea of norms clustering around specific themes is discussed in detail in NASSER, 2015. 
this sense, it is not surprising that the field of Human Rights is viewed by many as the axiological motor of globalization, at the opposite pole from that of the economy.

\section{GLOBAL LAW AS THE LAW IN A GLOBAL CONTEXT}

Considering that one could approach a state of the law in the world before globalization, or before the debate on globalization became central in social sciences during the last decades, and the state of the law after Globalization, the first conclusion would be that it does not cease to exist and to function as it did. In this sense, one could say that there are aspects of most of the law that do not change. To be more clear, national law continues to be created by the State and applied by it; international law continues to be created by treaties celebrated by States and by their behavior that becomes binding customs and applied by courts and institutions that are given power by the States. ${ }^{22}$

If we remain faithful to our acceptance of a larger meaning for law, as we did in the beginning of this paper, then all other law that existed besides national and international law also continues do exist and operate as it did.

The first effect of globalization on this previously existing law is not to change it - even if it may come to cause changes to it eventually, in its content and then in its functioning - but it is to shed light on the existence of an incredible plurality of legal ensembles. Plurality, multiplicity of the law, this is the first significant aspect of law under globalization. It is not created by globalization but becomes especially relevant under it. Even if globalization cannot be said to create, per se, the multiplicity and diversity of laws, norms and institutions, there certainly is a link between the processes of densification of social interaction and the expansion of the growing diversification of the normative universe, at the same time that there is a link with the growing specialization of the normative regimes. ${ }^{23}$

And this is because what globalization - once again, thought of as the multiplication and densification of social interactions covering the globe - will force onto the multiple and diverse universe of law is the interaction between its components. Thus, national laws will interact increasingly among them, as they will increasingly interact with international law and with other types of law, produced and implemented in other loci. International law will increasingly interact with the national and with the non-state produced law. Non-state law will intertwine and combine with national and international law.

22 See for more of this discussion NASSER, 2015.

23 For the growing expansion and specialization of Public International Law, which may serve as an illustration of our more encompassing argument, see ILC....; for the idea of specialization and multiplication of normative regimes as a social phenomenon, see TEUBNER and FISCHERLESCANO..., though we view with much criticism their rendering of the phenomenon; for a more encompassing reading and for the criticism just mentioned, see NASSER, 2015. 
There is no way to explain how exactly interaction takes place in general terms. One will only be able to map the ways in which normativity that springs from diverse sources meets and applies if the effort is directed at specific situations. And this is in itself testimony to the fact that possibilities will be unlimited. An illustration of this can be found in a recent thematic dossier published by the Brazilian International Law Review containing several case studies under the general label of Transnational Law. ${ }^{24}$

As mentioned before, the idea of a Global Law constituted by connectivity norms presented the difficulty of establishing the list of such norms, and we think this difficulty is the consequence of the open nature of the list of possible interactions.

However, Kjaer, the same author who conceives of the connectivity norms makes a very useful assertion on the object of connections which is that they are "...oriented towards the facilitation of transplantations, i.e., the extraction, transmission and incorporation of components of meaning, from one legally structured context to another...”.

We have not adopted as ours the notion of a Global Law consisting of connectivity norms. We see however how it is possible to understand the "extraction, transmission and incorporation of components of meaning" as an appropriate rendering of the general effect of the interactions of reference, incorporation, application of norms between different normative sets in a global context.

At the same time, it is precisely this function of transplantation of meaning that constitutes one of the main, and most problematic, features of law in global context, as it may clear the way to the overbearing exercise of power. ${ }^{25}$ This risk springs from the fact that because the multiplicity of norms and institutions, organized in numerous and diverse ways, interacting increasingly in countless forms, constitute a prescriptive world that is tending towards unmanageable complexity. Such complexity in the functioning of the instruments that are meant to determine social behavior and stabilize expectations entails the risk of a lesser degree of rule of law and of greater margin for arbitrary rule. ${ }^{26}$

\section{FINAL CONSIDERATIONS}

This paper proposes that the contemporary landscape of Law demands that it be understood from the viewpoint of the dialectics between law of globalization and law in globalization. Sections II and III have discussed the meaning we attach to these two qualifications of law: the former points out to norms and rules which intend to put in place the framework for global

24 Direito Transnacional. Revista de Direito Internacional, v. 13, n. 3, 2016.

25 DELMAS-MARTY, 1998.

26 See NASSER, 2015; NASSER e GHIRARDI, 2018. 
transactions and have the globe as its normative horizon; the latter comprises norms and rules which respond to or are affected, more or less directly, by this new global framework. This final section will focus on the dialectical nature of the relations between these normative ensembles.

The core analytical distinction presented in this paper (of/in) rests on the assumption that there is a necessary connection between these terms, that neither can be fully grasped without the other and that neither can be reduced to a straightforward result of the other. Any social process as broad and complex as globalization defeats all attempts to posit clear-cut causal links. The thorny problem of causality in history appears here in all its complexity.

The dialectical perspective adopted here takes into account this analytical complexity by suggesting that there are patterns of the contemporary interaction between legal systems which deserve special attention as their study may shed light on deeper dynamics of the phenomenon at hand. It argues that the field of law is affected by the local-global tension which shapes every other area of life in the era of globalization - economic, social, political.

Given the specific nature of law, however, such tension gives rise to a set of problems unlike those in any of these other fields. The impact of globalization on the role of States as primary normative sources puts in check one of the cornerstones of Modern legal thinking, practices and institutions. It destabilizes traditional readings of key elements of Law, e.g., the hierarchy and nature of normative sources, the validity of norms, the manner of their enforceability, the definition of proper jurisdiction - thereby posing a challenge to the building blocks of the legal field as it has been known for the past two centuries. It has transformed the very predicative structure thus far used to conceptualize law or, to use Castoriadis' apt phrase, it has made problematical "the already available logical-ontological schemes". ${ }^{27}$ The dialectical approach aims at capturing the movement of resignification of Law by identifying the core points of tension and main novel features it generates.

One such feature is that law in a global context tends to become more complex because of the increased interaction between legal ensembles. The above-mentioned erosion of the role of the State as the prime source of legal norms brings about the multiplication of loci for the production of law which, in turn, calls into question the mechanisms for the legitimation of the production of law and of its implementation.

The multiplication of authoritative normative loci vying for preeminence is root to deep tensions, with far-reaching social, economic and political

27 «significations imaginaires sociales » [qui] nous mettent en présence d'un mode d'être premier, originaire, irréductible, que nous devons...réfléchir à partir de lui-même sans le soumettre d'avance aux schèmes logiques-ontologiques déjà disponibles par ailleurs CASTORIADIS, 1975 , p. 526. 
impacts. The displacement of the State as the key source of law has meant that the traditional rationale for enacting law has also been shaken. States legislate in the name of the welfare of their citizens and this implies the political decision to establish a hierarchy of social goods. In democracies, it is the capacity to adjust normativity to the concurring demands of social groups that lends governments and legislatures their legitimacy. They have to be responsive to the values embraced by their nationals, their priorities and interests.

Non-state actors have a different rationale for creating and enforcing norms. They are often composed of similarly situated players placed in different parts of the globe (e.g., financial corporations) and their common interest may be at odds with the priorities of the communities where they are located. The tension between this governance-oriented normativity may clash with the government-oriented normativity of States.

Similar tensions emerge from the growing capacity of non-State actors to regulate specific areas of life (e.g., internet) whose characteristics make it particularly difficult for individual States to regulate or even to oppose the regulation thus created. This regulation by sector adds to the political tension springing from law in the global context, as the interests and goals of a certain sector are not necessarily those of the polities in which concerned actors are located. Mainly in what concerns the private sector, agents who perform norm-enacting tasks are not politically accountable and may, therefore, enact regulation in one area that affects the functioning of sectors not encompassed by their interests. The social costs of such a normative competition may be daunting.

Another set of challenges for Law in the context of globalization is represented by the growing divide, within national legal communities, created by the quest for achieving the expertise needed for counselling and litigation in the complex network of multiple normativities. The goal of forming global lawyers has become a key feature of current legal education. Law students and professionals from all over the world attend American or American-style LLM Programs which offer them the global perspective needed to aptly perform on a global scale. Over time, these lawyers become professionally quite detached from their colleagues who practice municipal law. This gap within the profession is spurred by, and replicates, similar gaps in legal education.

All these tensions, as it is argued here, develop dialectically, with changes in one pole triggering transformations in the other. The broad framework for the dynamics of this opposition, it has been argued in this paper, is that made up by the key distinction between law of globalization and law in globalization. 


\section{REFERENCES}

BACKER, L.C. Economic Globalization and the Rise of Efficient Systems of Global Private Lawmaking: Wal-Mart as Global Legislator, In: University of Connecticut Law Review, n. 39, 2007.

BARTOLI, Henry. La mondialisation doit être gouvernée. In : Revue Quart Monde, $\mathrm{n}^{\circ}$ 175, septembre 2000.

BOLI, J.; THOMAS, G. M. Constructing World Culture - International Nongovernmental Organizations Since 1875. California: Stanford University Press, 1999.

CASTORIADIS, Cornelius. L'institution imaginaire de la société. Paris : Seuil, 1975.

CHEVALLIER, Jacques. L’État post-moderne. Paris, LGDJ, 2017.

COLLINS, Richard. The Slipperiness of 'global law'. Oxford: Oxford Journal of Legal Studies, 2017, v. 37, p. 1-26.

DARIAN-SMITH, Darian. Laws and Societies in Global Contexts Contemporary Approaches. Cambridge: Cambridge University Press, 2013.

DELMAS-MARTY, Mireille. Trois défis pour un droit mondial. Paris: Seuil, 1998.

DUMEZ, H. et JEUNEMAITRE, A. Comprendre la globalisation. In: La Gazette de la société et des techniques, $n^{\circ} 4$, septembre 2000.

FARIA, José Eduardo (org.). Direito e Globalização Econômica - Implicações e Perspectivas. São Paulo: Malheiros, 1996.

FOZ MANGE, Flavia. As Características do Direito Transnacional como Metodologia: Análise sob o enfoque dos Aspectos Processuais da Arbitragem. Brasília: Revista de Direito Internacional, v. 13, n 3, 2016.

GIDDENS, Anthony. The Consequences of Modernity. Stanford, Stanford University Press, 1990.

GROSS CUNHA, Luciana et. al. (eds), The Brazilian Legal Profession in the Age of Globalization. Cambridge, Cambridge University Press, 2018.

HELD, David et. alt. (eds). Global Transformations. Cambridge: Polity Press, 1999.

HURREL, Andrew. On Global Order - Power, Values, and the Constitution of International Society. Oxford: Oxford University Press, 2007. 
KOSKENNIEMI, Martti. Fragmentation of International Law: difficulties arising from the diversification and expansion of international law. In: International Law Commission, fifty-eight session. Geneva: General Assembly of the United Nations, 2006.

KJAERT, Paul. Global Law as Inter-contextuality and as Inter-legality. In: KLABBERS, Jan and PALOMBELLA, Gianluigi, (eds). The Challenge of Interlegality. Cambridge: Cambridge University Press, 2019, p. 302-318.

KJAER, Paul. Transnational Normative Orders: The Constitutionalism of Intraand Trans-Normative Law. Indiana Journal of Global Legal Studies, 2013, p. 777-803.

LE GOLF, Pierrick. Global Law: A Legal Phenomenon Emerging from the Process of Globalization. Indiana Journal of Global Legal Studies, 2007, v. 14.

LINDAHL, Hans. Fault Lines of Globalization. Legal Order and the Politics of A-Legality. Oxford: Oxford University Press, 2014.

LOUGHLIN, Martin. The misconceived search for global law. In: Transnational Legal Theory, 2017, p. 353-359.

NASSER, S. H.. Direito global em pedaços: fragmentação, regimes e pluralismo. Revista de Direito Internacional, v. 12, p. 98-126, 2015.

NASSER, S. H. Rule of Law e Direito International: uma Nova Aproximação. In: Oscar Vilhena Vieira; Dimitri Dimoulis. (Org.). Estado de Direito e o Desafio do Desenvolvimento. $1^{a}$ ed. São Paulo: Saraiva, 2011, v. 1, p. 59-78.

NASSER, S. H.; GHIRARDI, J. G.. O que se diz e o que se cala: a governança entre a fuga do Direito e a busca pelo controle. NOMOS (FORTALEZA), v. 38, p. 731-743, 2018.

OST, François e KERCHOVE, Michel de. De la pyramide au réseau? Pour une théorie dialictique du droit. Bruxelles: Presses des Facultés Universitaires Saint Louis, 2002

PALOMBELLA, Gianluigi. Global Law and the Law on the Globe. Layers, Legalities and the Rule of Law Principle. Italian Journal of Publica Law, 2012, v. 4, p. 53-92.

SALAH, Mahmoud Mohamed. Les Contradictions du droit mondialisé. Paris: PUF, 2002.

SALMON, Jean. Dictionnaire de Droit International Public. Bruxelles: Bruylant, 2001.

SANTOS, Boaventura (org.). A Globalização e as Ciências Sociais. $4^{\mathrm{a}}$ ed. São Paulo: Cortez Editora, 2002. 
SCHIFF BERMAN, Paul. Global Legal Pluralism: A Jurisprudence ofLaw Beyond Borders. Cambridge: Cambridge University Press, 2014.

SHAPIRO, Martin. The Globalization of Law. Indiana Journal of Global Legal Studies Article, 1993, v. 1, p. 973-994.

STIGLITZ, Joseph. A Globalização e seus Malefícios. São Paulo: Futura, 2002.

TERRÉ, François. La Mondialisation entre illusion e utopie. Paris: Dalloz, 2003.

FISCHER-LESCANO, Andreas; TEUBNER, Gunther. Regime-Collisions: The Vain Search for Legal Unity in the Fragmentation of Global Law. Michigan: Michigan Journal of International Law, 2004, v. 25, p. 999-1046.

TWINING, William. Implications of "globalisation" for law as a discipline. London: Legal Theory and the Legal Academy, 2010, v. 3.

TWINING, William. Globalisation \& Legal Theory. Cambridge: Cambridge University Press, 2000.

WALKER, Neil. Intimations of Global Law. Cambridge: Cambridge University Press, 2014.

WHITE, Hayden V. Metahistory: The Historical Imagination in NineteenthCentury Europe. Baltimore: Johns Hopkins University Press, 1973.

PEER, Zumbansen. Defining the Space of Transnational Law: Legal Theory, Global Governance, and Legal Pluralism. Journal of Transnational Law \& Contemporary Problems. 
